\title{
The In-Service Training Program of the University of Pennsylvania Library
}

Mr. Hirsch is assistant librarian, preparations division, University of Pennsylvania Librfary.

\section{Introduction}

$\mathrm{W}$ HEN the University of Pennsylvania Library announced in 1946* its experimental In-Service Training Program, the project was little more than an idea developed with some care and in some detail. It lacked, however, the concrete and specific procedures necessary to put the plan into operation. It is the purpose of this article to report on the organization and operation of the experiment.

\section{Organization}

During the winter and spring of 1947 a small group of University of Pennsylvania librarians met informally to make decisions on the following points: ( $\mathrm{I}$ ) desirable qualifications of candidates; (2) procedures of selection and of administration; (3) scope and detail of practice work; (4) scope and method of instruction; (5) selection of instructors; (6) examination and certification of trainees. These meetings, or preseminars, resulted in specific decisions which were subsequently translated into action.

From the start it had been agreed to limit admission to a small number of students of either sex. The maximum was set at five,

* Conference of Eastern College Librarians. College and Research Libraries, 8:126-28, April 1947. with an understanding that a limited number of staff members would be permitted to attend as auditors, a privilege of which some few availed themselves. Trainees were to be appointed as regular members of the staff and paid at semiprofessional rates. Their library schedule was to be reduced from an average of 37 hours per week required of other staff members, to 30 hours. This special consideration was given in order to ease their additional burden of 6 hours of instruction and an estimated 8 to 12 hours of preparation. As applicants came for personal interviews, it was stated emphatically that the proposed two-year program of instruction and internship would mean hard work with little material reward; that we were offering what we hoped would be good experience and training, but no formal degree and no guarantee of professional recognition beyond the University of Pennsylvania libraries. We stated that we were prepared to put into the trainees' education more individual attention than they could reasonably expect in most other programs, but that few of us had experience in teaching and that the entire program was experimental.

Requirements for admission were possession of a bachelor's degree, a better than average academic record, some language ability, a convincingly expressed desire to become a research librarian, sufficient stamina to withstand the rigor of hard 
work, and most important perhaps, a personality, as revealed in interviews, acceptable to the director and his three immediate assistants. Announcements and invitations to apply for admission were sent to colleges and universities of the area only. This regional limitation was decided upon in the hope of thus lessening the trainees' financial burden. Altogether we received 29 inquiries, of which roughly one-third were actual applications. We accepted four applicants, of whom two had already been employed in the University of Pennsylvania Library during the winter and spring of 1947. The background and education of the four successful candidates can best be judged from the following brief curricula vitae:

\section{Trainee A.}

b. 1918.

Educ.: B.A., 1947, University of Pennsylvania (College of St. Elizabeth, 19361939; University of Kansas City, 19391940; University of Pennsylvania, 19461947) ; major: English, Sociology. Business school, March-July 1940.

Scholastic honors: Graduated fifth place in high school class of 527 . On Dean's list at College of St. Elizabeth.

Experience: Secretary, November 1940March 1943. Ensign, U.S. Naval Reserve (W.R.), March 1943-February 1946.

Languages: Latin, French.

Trainee B.

b. 1912 .

Educ.: B.A., 1934, Smith College (Junior year at Universities of Perugia and Florence); major: Italian.

Scholastic honors: Phi Beta Kappa. Degree, Summa cum laude. Won Italian prize at Smith College.

Experience: Clerk, secretary, and executive at Pennsylvania Hospital, September I944-June 1947.

Languages: Italian, Spanish, French, German.
Trainee C.

b. 1923.

Educ.: Preparatory education in French and Belgian convents. B.A., 1945, University of Pennsylvania; major: English, Greek. Business school.

Scholastic honors: Phi Beta Kappa. Degree, Cum laude. Honors in major subject.

Experience: Tutoring in French, English, History, Greek. Clerical work, JuneSeptember 1943. University Press research assistant, June 1945-September 1946. Curtis Publishing Company, advertising work-statistical aspect, to May 1947.

Languages: French, German, Greek, Latin, Chinese.

\section{Trainee D.}

b. 1921 .

Educ.: B.S. in Education, 1945, Wilson's Teacher's College; major: English. Studying at University of Pennsylvania, 1946, for M.A. in Indo-European linguistics; major: German; also taking Lithuanian and Russian syntax.

Experience: Clerical work, August 1941September 1946.

Languages: German, Russian.

\section{First Year of Training}

The four appointments made, positions budgeted and approved, and outlines of instruction in hand, the program started as scheduled on July I, 1947. Since courses did not begin until September, the intervening months permitted instructors to organize their courses and the trainees to familiarize themselves with the work in the University Library. Actual teaching started September 16 with two sessions of general indoctrination in which all instructors participated. These sessions covered what is sometimes called-controversially, as we well remember-philosophy of librarianship. We also discussed the entire program and announced that the courses would be largely of the seminar or laboratory type, though it was left to the 
individual instructor to choose the technique deemed most appropriate for the subject taught.

Courses are briefly listed in Table I. technical or clerical nature." Answer him.

2. Choose any subject taught during the past year as a part of our In-Service Training Program and discuss its relevance, or lack thereof, to librarianship.

Table I

Courses, Academic Year, 1947-48

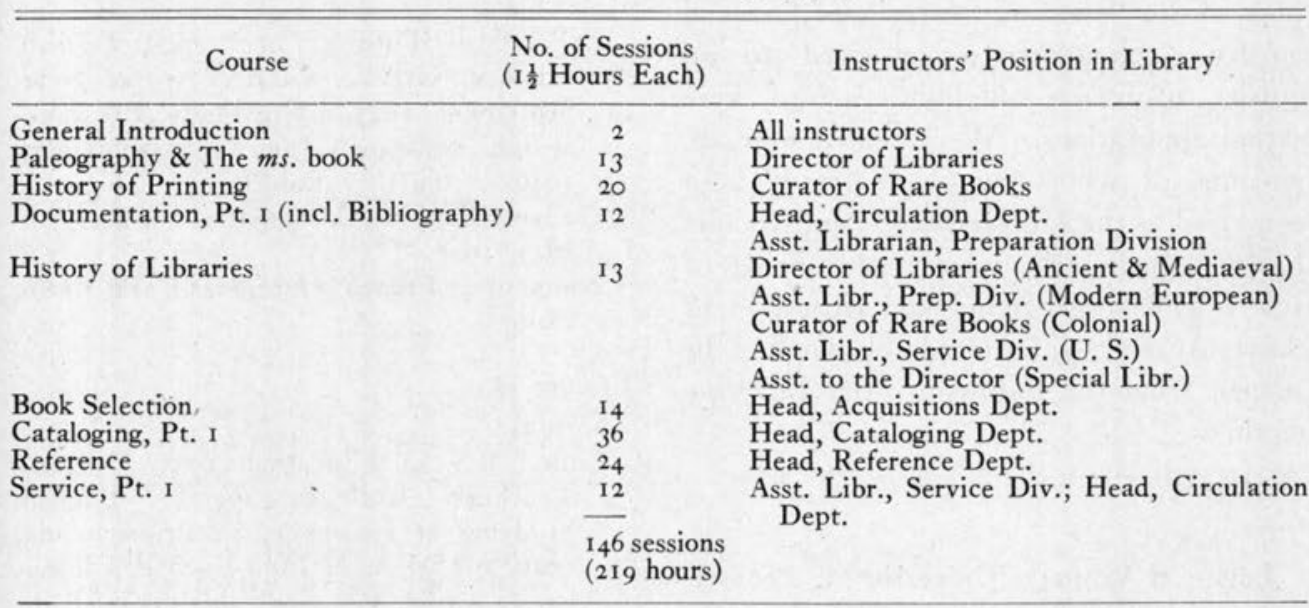

Some of the courses were the responsibility of more than one instructor. This method served to distribute their load and made it possible to assign responsibility in accordance with special qualifications. As far as could be observed, the trainees neither objected to nor suffered from this method of joint conduct of courses.

The teaching was largely fitted into the regular library hours. Two sessions weekly were held from 9:00 a.m. to I0:30 a.m., and two others from $4: 00$ p.m. to $5: 30$ p.m. Instructors were permitted to test students in connection with their courses. In addition, at the end of the first year, the trainees were given a written examination allowing them $1 \frac{1}{2}$ hours to answer three of the following five questions:

I. Mr. Smith, an educated and influential gentleman, declares in an argument with you, "It is entirely unnecessary for a librarian to be acquainted with the methods and problems of research, since his work is of a purely
3. What does the printed book (using the word as a collective noun) owe, and not owe, to the manuscript (using the word in the same general sense)?

4. Indicate what cataloging skills are useful to (a) a worker in acquisitions and (b) a worker in reference.

5. Prepare an outline to accompany an application to a foundation for a research grant in bibliography or librarianship.

The results of the examination proved to our satisfaction that the four trainees had acquired-if they did not possess it before - the ability to analyze properly relevant problems, to organize their reactions, and to present them in acceptable form. Certain weaknesses were recognized and subsequently discussed with the students. None of the instructors marked any of the answers unsatisfactory. However, their appraisal showed a healthy divergence of opinion, reflecting their particular emphasis on different qualifications.

It was stated at the outset that courses 
would be confined largely to historical and theoretical aspects of librarianship. Knowledge and experience of applied librarianship were to be acquired through practice work. We therefore planned a comprehensive rotation schedule, to which we did not adhere rigidly since the previous experience of two of the trainees was taken into account and since requests for special experience were considered favorably. The rotation schedule appears as Table 2 , and shows that all four trainees will have gained experience in all major departments by the expiration of the internship.
The choice of graduate courses was left entirely to the students. Table 3 (see next page) which includes their registration in the Graduate School, gives a convenient indication of their choice of specialization.

\section{Conclusions}

It is perhaps too early to draw conclusions, particularly since they are by necessity subjective. However, in the opinion of the director of libraries and the writer of the present article, the experiment is proving worth while. We believe we have found four excellent trainees and are giving

Table 2

Rotation Schedule of Practice Work

\begin{tabular}{|c|c|c|c|c|c|c|}
\hline Trainee & $\begin{array}{c}\text { Jy. I-Dec. 3I } \\
\text { I } 947\end{array}$ & $\begin{array}{c}\text { Jan. } \mathrm{I}-\mathrm{Mar} \text {. } 3 \mathrm{I} \\
\mathrm{I} 94^{8}\end{array}$ & Apr. $\mathrm{I}-\mathrm{Je} .30$ & $\begin{array}{c}\text { Jy. I-Aug. } 3 \mathrm{I} \\
\text { I } 948\end{array}$ & $\mid \begin{array}{c}\text { Sep. } \\
\text { I } 948\end{array}$ & $\begin{array}{c}\text { Jan. I-Je. } 30 \\
\text { 1948 }\end{array}$ \\
\hline $\begin{array}{l}\mathrm{A} \\
\mathrm{B}\end{array}$ & $\begin{array}{l}\text { Circulation } \\
\text { Acquisitions }\end{array}$ & $\begin{array}{l}\text { Acquisitions } \\
\text { Rare Book } \\
\text { Coll. }{ }^{3}\end{array}$ & $\begin{array}{l}\text { Acquisitions } \\
\text { Cataloging }\end{array}$ & $\begin{array}{l}\text { Reference } \\
\text { Cataloging }\end{array}$ & $\begin{array}{l}\text { Reference } \\
\text { Circulation }\end{array}$ & $\begin{array}{l}\text { Cataloging } \\
\text { Reference }\end{array}$ \\
\hline $\mathrm{C}^{1}$ & Cataloging ${ }^{3,4}$ & Reference & Reference & Acquisitions & $\begin{array}{l}\text { Service Div. } \\
\text { (general) }\end{array}$ & $\begin{array}{l}\text { Special as- } \\
\text { signment }\end{array}$ \\
\hline $\mathrm{D}^{2}$ & Reference & Circulation & $\begin{array}{l}\text { Math.-Phys- } \\
\text { ics }{ }^{3} \text { Dept. } \\
\text { Library }\end{array}$ & Cataloging & Acquisitions & $\begin{array}{l}\text { Special as- } \\
\text { signment }\end{array}$ \\
\hline
\end{tabular}

1 Acquisitions experience before July 1, 1947.

2 Cataloging experience before July 1, 1947.

Trainee's request.

4 Three weeks in binding department.

\section{Second Year of Training}

Plans for the second year of instruction have been slightly altered since the program was inaugurated. Originally we had hoped to permit elective courses. However, since the first year's experience showed that the burden of the program on instructors was heavy we decided to reduce the number of sessions, though retaining all courses as compulsory instruction, requiring instead that each student register in the Graduate School of the University for two or more hours of course work per week. It is hoped that all four trainees will use the credits thus acquired toward a master's degree. them an education which promises to make them outstanding members of the library profession. The experiment, on the other hand, has put a great burden on the instructional staff. The enthusiasm and interest of most of the instructors has enabled them to carry this extra burden without neglecting their regular work. But it is doubtful whether such a program could be made a regular function of the University of Pennsylvania Library without releasing the instructors from some of their library responsibilities. It therefore remains an open question whether the University of Pennsylvania Library should continue such a program. It is noticed with some satisfaction 
that revised programs announced by several library schools indicate a trend toward greater emphasis on the theoretical aspect of librarianship and on books. Should this impression be correct, it may well be argued that there is no longer a valid reason for us to continue our experiment, even though it has been gratifying.

Courses, Academic Year 1948-49

\begin{tabular}{|c|c|c|c|}
\hline Course & \multicolumn{2}{|c|}{$\begin{array}{l}\text { No. of Sessions } \\
\text { (I } \frac{1}{2} \text { Hours Each) }\end{array}$} & Instructors' Position in Library \\
\hline $\begin{array}{l}\text { Printing (social eco- } \\
\text { nomic \& related as- } \\
\text { pects) } \\
\text { Documentation, Pt. } 2 \\
\text { Cataloging, Pt. 2 } \\
\text { Service, Pt. 2 } \\
\text { Administration } \\
\text { Reading } \\
\text { Book Trade }\end{array}$ & $\begin{array}{l}13 \\
28 \\
31 \\
31 \\
20 \\
20 \\
13\end{array}$ & $\begin{array}{r}10 \\
12 \\
26 \\
15 \\
20 \\
10 \\
6\end{array}$ & $\begin{array}{l}\text { Asst. Librarian, Prep. Div. } \\
\text { Head, Circulation Dept. Asst. Libr., Prep. Div. } \\
\text { Head, Cataloging Dept. } \\
\text { Asst. Libr., Service Div. Head, Circulation Dept. } \\
\text { Director of Libraries, Asst. to the Director } \\
\text { Asst. Libr., Service Div. } \\
\text { Asst. Libr., Prep. Div. }\end{array}$ \\
\hline & Trainee & \multicolumn{2}{|c|}{ Graduate School Instruction } \\
\hline & $\begin{array}{l}\text { A } \\
\text { B } \\
\text { C } \\
\text { D }\end{array}$ & \multicolumn{2}{|c|}{$\begin{array}{l}\text { English Literature } \\
\text { Romance Languages } \\
\text { Oriental Studies } \\
\text { Russian Language and Literature }\end{array}$} \\
\hline
\end{tabular}

\section{Education for Future Librarians}

(Continued from page 102)

of our time-personal relationships in modern society. We no longer trust each other; honesty and frankness are at a premium; faith and confidence have tended to disappear. "I trust nobody" increasingly characterizes modern society; the sense of insecurity in human relationships is widespread. Fear haunts us; fear of being double-crossed; fear of being "taken in"; fear of "sticking our necks out"; fear of being victimized by a black marketeer. Fear and lack of faith are partially responsible for the hysteria, prejudice, religious fanaticism and diplomatic chicanery which characterizes the international scene today. Many of us will undoubtedly agree with the contention of Professor Howard Mum- ford Jones, of Harvard University, that perhaps the most tremendous task before higher education is to seek out means of restoring between human being and human being that calm and confident relationship which our western culture has lost, is losing and will continue to lose until psychologist and physician, sociologist and anthropologist, by combining their studies, can perhaps restore this faith to western man.

The person looking forward to a career as a librarian, who has this basic foundation in general education and on top of it builds the techniques and skills which he must have, is admirably equipped not only for his duties as a librarian but for his role as citizen as well. 